\title{
Prevalence of Deletional Alpha Thalassemia and Sickle Gene in a Tribal Dominated Malaria Endemic Area of Eastern India
}

\author{
Prasanta Purohit, ${ }^{1}$ Snehadhini Dehury, ${ }^{1}$ Siris Patel, ${ }^{2}$ and Dilip Kumar Patel ${ }^{3}$ \\ ${ }^{1}$ Sickle Cell Clinic \& Molecular Biology Laboratory, Veer Surendra Sai Medical College, Burla, Sambalpur, Odisha 768017, India \\ ${ }^{2}$ Department Medicine, Sickle Cell Clinic \& Molecular Biology Laboratory, Veer Surendra Sai Medical College, \\ Burla, Sambalpur, Odisha 768017, India \\ ${ }^{3}$ Department of Medicine, Sickle Cell Clinic \& Molecular Biology Laboratory, Veer Surendra Sai Medical College, Qr. 3R/27, \\ Doctors Colony, Burla, Sambalpur, Odisha 768017, India
}

Correspondence should be addressed to Dilip Kumar Patel; drdilippatel25@gmail.com

Received 15 January 2014; Accepted 18 February 2014; Published 11 March 2014

Academic Editors: S. E. Cox and J. L. Vives-Corrons

Copyright (C) 2014 Prasanta Purohit et al. This is an open access article distributed under the Creative Commons Attribution License, which permits unrestricted use, distribution, and reproduction in any medium, provided the original work is properly cited.

\begin{abstract}
Inherited hemoglobin disorders like alpha thalassemia and sickle gene are common in the Indian subcontinent. These disorders in the heterozygous state act as malaria resistance genes and influence the susceptibility to Plasmodium falciparum malaria. There is inadequate knowledge about the epidemiology of these malaria resistance genes in the tribal dominated malaria endemic region of the state of Odisha in eastern India. A cross sectional prevalence study was undertaken in 594 subjects in five tribal populations in this region, namely, Sahara (42.4\%), Kutia Kandha (30.0\%), Kuda (15.8\%), Gond (9.8\%), and Oraon (2.0\%). Sickling test, Hb electrophoresis, HPLC, and molecular studies were undertaken to diagnose the prevalence of sickle allele, $\beta$-thalassemia allele, and deletional alpha thalassemia. Sickle and $\beta$ thalassemia alleles were found in $13.1 \%$ and $3.4 \%$ of subjects, respectively. Sickle allele was found both in heterozygous (10.1\%) and homozygous state (3.03\%). The prevalence of alpha thalassemia was $50.84 \%$ with an allelic frequency of 0.37. Both $\alpha^{-3.7}$ and $\alpha^{-4.2}$ alpha thalassemia were detected with an allele frequency of 0.33 and 0.04 , respectively. The high prevalence of alpha thalassemia and sickle gene in this population is probably due to selection pressure of endemic malaria in this part of India.
\end{abstract}

\section{Introduction}

Inherited hemoglobin disorders are the commonest monogenic diseases in humans [1]. Between 3,00,000 and 4,00,000 babies are born each year with serious hemoglobin disorders and up to $90 \%$ of these births occur in low and middle income countries [2]. Many of these inherited hemoglobin disorders are malaria resistance genes and in the heterozygous state influence the susceptibility to $P$. falciparum malaria $[3,4]$. However our knowledge regarding their epidemiology and the pathophysiological basis of malaria protection is inadequate [3].

Alpha thalassemia, a commonly encountered inherited hemoglobin disorder presents in one of four clinical phenotypes (a) clinically asymptomatic (occurring in silent carrier state) due to a single alpha gene deletion $(-\alpha / \alpha \alpha)$ with no or little hematological changes [5], (b) alpha thalassemia minor due to deletion of two genes $(-\alpha /-\alpha ;--/ \alpha \alpha)$, (c) hemoglobin $\mathrm{H}$ disease due to deletion of three of the four alpha genes $(--/-\alpha)$, and (d) Barts hydrops fetalis, a fatal hemoglobin produced due to deletion of all four alpha genes $(--/--)$ [5]. Both alpha thalassemia minor and hemoglobin $\mathrm{H}$ lead to a phenotype resembling $\beta$ thalassemia intermedia [4]. Alpha thalassemia is especially frequent in Mediterranean countries, South East Asia, Africa, and the Indian subcontinent [1]. It most frequently results in a mild form of alpha thalassemia due to single gene deletion from the chromosome-16 [6]. Although alpha thalassemia has been documented from various parts of India [7-12], there is no population based cross sectional prevalence study of this disorder from the state of Odisha.

The sickle gene, another malaria resistance gene is widely distributed in various parts of the world including the Indian 
subcontinent, where carrier frequencies range from $5 \%$ to $40 \%$ [4]. The sickle gene is highly prevalent in western districts of Odisha with a frequency of $21 \%$ [13]. In a few tribes studied, the frequency of sickle gene was found to be $8 \%$ [14].

Tribal persons are considered to be the indigenous people of the land and they usually live in isolates in natural and unpolluted surroundings away from civilization. The Indian subcontinent comprises 635 different communities including 75 primitive tribes. The state of Odisha located in eastern India occupies a unique place in the tribal map of the country with the largest number of tribal communities (62 tribes including 13 primitive tribes) [15]. Due to lack of confounding factors like migration and population admixture, this population is ideally suited for studying the relationship of alpha thalassemia, sickle gene, and historical malaria endemicity [16].

Malaria is an important public health problem in India and contributes two-thirds of the parasitologically confirmed malaria cases in the Southeast Asia region [17]. The state of Odisha located in eastern India contributes to $23 \%$ of malaria positive cases, $50 \%$ of $P$. falciparum cases, and $15 \%$ of the deaths in India [18]. Majority of the tribal population in the state of Odisha live in high risk areas of malaria [19].

Accurate assessment of the prevalence of various hemoglobin disorders like alpha thalassemia and sickle cell anemia is important for two reasons. (1) Improvement in hygiene, nutrition, and the control of infection has led to reduced childhood mortality and increased survival of babies with severe hemoglobin disorders like sickle cell anemia and thalassemia and presents a challenge for limited health resources in developing countries like India. As a result of such demographic changes, the impact of these diseases is now being felt all over the Indian subcontinent [4]. In this context, reliable estimates of the populations affected by hemoglobin disorders are desirable to guide publichealth priority settings [20]. (2) Emerging resistance of anopheles mosquitos against conventional insecticides and drug resistance strains of $P$. falciparum has led to global resurgence of $P$. falciparum malaria. Host resistance genes like alpha thalassemia and sickle gene influence the population structure of $P$. falciparum, notably in the genes of $P$. falciparum that affects the success and virulence in infection [21]. Studies of these malaria protection genes in the human host and their interaction with $P$. falciparum will advance our understanding of malaria pathogenesis leading to development of an effective malaria vaccine and improved treatment strategies. The existing knowledge about the epidemiology of malaria resistance genes like alpha thalassemia and sickle gene in the tribal dominated malaria endemic region of Odisha is inadequate, because of which we undertook this study.

\section{Materials and Methods}

The study was undertaken at Sickle Cell Clinic and Molecular Biology Laboratory, Veer Surendra Sai Medical College, Burla, located in the state of Odisha, in eastern India. This hospital caters for a population of about 40 million from the western part of Odisha state and adjoining districts of Chhattisgarh state.

This cross sectional prevalence study was carried out in three tribal dominated villages situated in western Odisha with a population of 403,394 , and 432 , respectively. Two of the villages were in the district of Bargarh and the other in Kalahandi district. In the three villages $48.6 \%(196 / 403)$, $49.2 \%$ (194/394), and $47.2 \%(204 / 432)$ of the population were sampled. When combined $48.3 \%$ (594/1229) of the total population in the three villages was studied. It was undertaken as a component of Odisha Sickle Cell Project, under which field studies are carried out in western districts of Odisha to estimate the prevalence of inherited hemoglobin disorders. During the field studies, a routine health check-up was carried out on all the subjects. Detailed personal information and clinical characteristics were entered in a predesigned format. Information about the importance of malaria, alpha thalassemia, and sickle cell anemia and their inheritance pattern were imparted to the villagers including various screening methods and importance of vaccination of children. The villagers were made aware of the facilities for free diagnosis, treatment, and counselling of the inherited hemoglobin disorders at the nodal centre of Veer Surendra Sai Medical College, Burla.

Written informed consent was obtained from the study subjects or guardians (in case of children) before collecting the blood by trained personnel, which is a part of ethical clearance from the institute. Five milliliters of EDTA venous blood was collected in vacutainer (Becton, Dickinson and Company) and stored between 2 and 8 degrees in a vaccine carrier and transported to the Sickle Cell Clinic and Molecular Biology Laboratory within 24 hours for various hematological and molecular analyses.

Sickling slide test and alkaline agarose gel hemoglobin electrophoresis (pH-8.6) were carried out within 3 days. All samples were subjected to Cation-exchange high performance liquid chromatography (CE-HPLC) analysis using Variant II- $\beta$ thalassemia short programme (Bio-Rad laboratories, Hercules, CA, USA) to determine the quantities of different hemoglobin variants. Genomic DNA was extracted from whole blood by a standard phenol chloroform extraction method [22]. The presence of the $\beta^{\mathrm{S}}$ mutation was confirmed by amplified refractory mutation system-PCR (ARMS-PCR) [23]. Subjects with $\mathrm{HbA}_{2}$ of more than 3.5\% were analyzed for $\beta$ thalassemia mutations $\left(\beta^{\mathrm{T}}\right)$ by procedures described earlier [24]. Alpha globin gene deletions $\left(\alpha^{-3.7}\right.$ and $\left.\alpha^{-4.2}\right)$ were detected by gap-PCR [25].

The study was approved by the Institutional Ethical Committee.

\section{Results}

In the present study 594 subjects were included, of which 390 (65.7\%) belonged to the district of Bargarh and the rest 204 (34.3\%) were from Kalahandi district. The subjects belonged to five tribal communities namely Sahara $(252,42.4 \%)$, Kandha (Kutia), (178, 30.0\%), Kuda (Mirdhas) (94, 15.8\%), Gond $(58,9.8 \%)$, and Oraon $(12,2.0 \%)$. Majority of the 
TABLE 1: Demographic features of study subjects with allelic frequency of different hemoglobinopathies.

\begin{tabular}{|c|c|c|c|c|c|}
\hline & Sahara & $\begin{array}{c}\text { Kandha } \\
\text { (Kutia) }\end{array}$ & Oraon & Gond & $\begin{array}{c}\text { Kuda } \\
\text { (Mirdhas) }\end{array}$ \\
\hline Number (\%) & $252(42.4 \%)$ & $178(30.0 \%)$ & $12(2.0 \%)$ & $58(9.8 \%)$ & $94(15.8 \%)$ \\
\hline District & $\begin{array}{c}\text { Bargarh and } \\
\text { Kalahandi }\end{array}$ & Kalahandi & Kalahandi & Bargarh & Bargarh \\
\hline Age (Years) & $21.6 \pm 18.3$ & $18.7 \pm 18.0$ & $20.02 \pm 13.5$ & $27.9 \pm 21.7$ & $22.5 \pm 19.2$ \\
\hline \multicolumn{6}{|l|}{ Sex } \\
\hline Male & 118 & 96 & 8 & 26 & 44 \\
\hline Female & 134 & 82 & 4 & 32 & 50 \\
\hline$\beta^{S}$ allele frequency & 0.08 & 0.07 & 0 & 0.17 & 0.05 \\
\hline$\beta^{\mathrm{T}}$ allele frequency & 0 & 0.03 & 0 & 0 & 0 \\
\hline$\alpha^{-3.7}$ allele frequency & 0.3 & 0.41 & 0.25 & 0.28 & 0.28 \\
\hline$\alpha^{-4.2}$ allele frequency & 0.06 & 0.03 & 0 & 0 & 0.04 \\
\hline
\end{tabular}

$\beta^{\mathrm{S}}$ : sickle gene mutation; $\beta^{\mathrm{T}}: \beta$ thalassemia gene mutation.

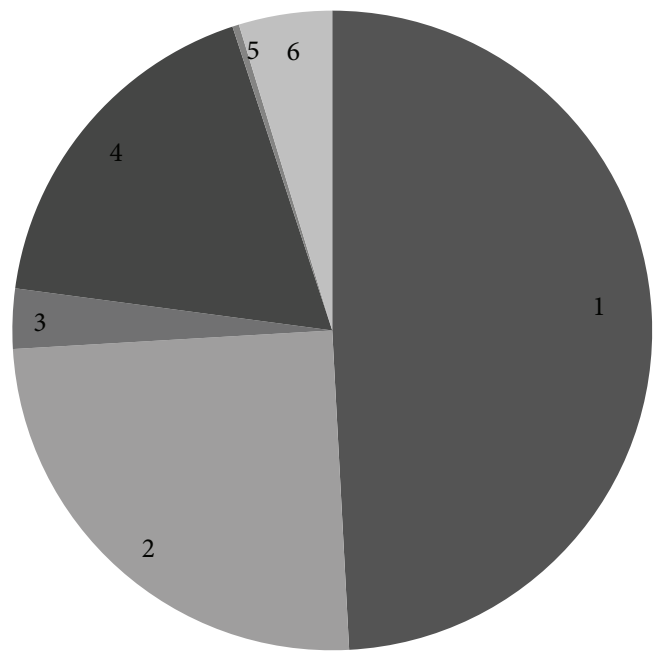

(1) Normal alpha globin gene $(\alpha \alpha / \alpha \alpha)-49.16 \%$

(2) $\alpha^{-3.7}$ heterozygotes $(-3.7 \alpha / \alpha \alpha)-24.92 \%$

(3) $\alpha^{-4.2}$ heterozygotes $(-4.2 \alpha / \alpha \alpha)-3.03 \%$

- (4) $\alpha^{-3.7}$ homozygotes $(-3.7 \alpha /-3.7 \alpha)-17.85 \%$

(5) $\alpha^{-4.2}$ homozygotes $(-4.2 \alpha /-4.2 \alpha)-0.34 \%$

(6) Double heterozygotes $(-3.7 \alpha /-4.2 \alpha)-4.71 \%$

Figure 1: Prevalence of deletional alpha thalassemia alleles in the study subjects $(n=594)$.

Sahara were found in the district of Bargarh (94.4\%). Kandha and Oraon were found in Kalahandi district and Gond and Kuda in Bargarh district. The mean age of the study subjects was $21.5 \pm 18.7$ years (range, $1-80$ years) and $50.8 \%$ were female (Table 1).

The prevalence of alpha thalassemia alleles in this study population was $50.84 \%$ (Figure 1) with an allelic frequency of 0.37. Both $\alpha^{-3.7}$ and $\alpha^{-4.2}$ deletional alpha thalassemia were detected with an allelic frequency of 0.33 and 0.04 , respectively (Table 1). The details of alpha thalassemia distribution are depicted in Table 1 and Figure 1.

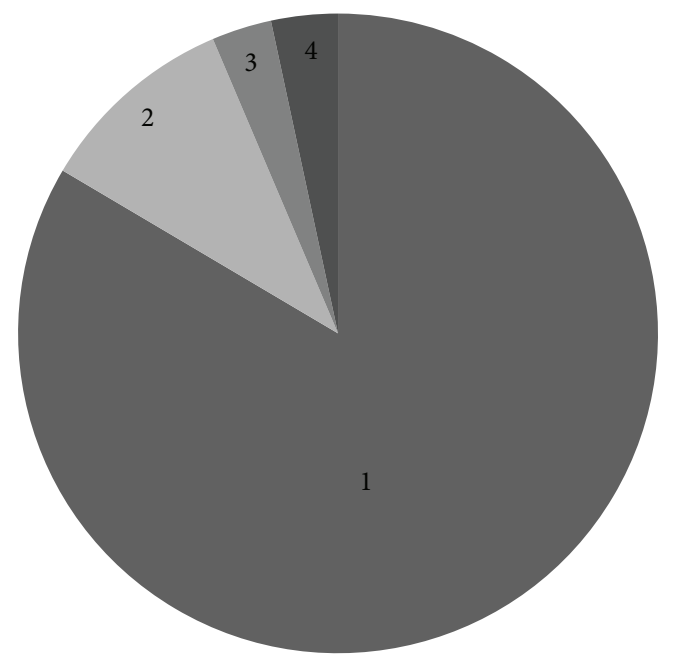

(1) Normal genotype (HbAA)—496 (83.5\%)

(2) Sickle allele in heterozygous state-60 (10.1\%)

(3) Sickle allele in homozygous state-18 (3.0\%)

(4) $\beta$ thalassemia allele $-20(3.4 \%)$

Figure 2: Prevalence of sickle allele and $\beta$ thalassemia allele in the study subjects $(n=594)$.

The prevalence of sickle allele was $13.1 \%$ with an allelic frequency of 0.08 . Sickle allele was found both in heterozygous state (10.1\%) and homozygous state, that is, sickle cell anemia (3.03\%) (Figure 2). The highest prevalence of sickle allele was observed in Gond (31.0\%) followed by Sahara (14.3\%), Kandha (9\%), and Kuda (8.51\%). We did not find sickle allele in Oraons (Figure 3). Heterozygous $\beta$ thalassemia was found in $3.37 \%$ of subjects and allelic frequency was 0.017 (Table 1). None of the subjects had beta thalassemia major or compound heterozygous state of sickle- $\beta^{+}$thalassemia. IVS1$5(\mathrm{G} \rightarrow \mathrm{C})$ was the only $\beta$ thalassemia mutation detected and all subjects belonged to Kandha tribe. In Khandha tribe all the three alleles (sickle allele, $\beta$ thalassemia, and alpha 
TABLE 2: Prevalence of alpha thalassemia allele, sickle allele, and $\beta$ thalassemia allele in different age groups in tribal population.

\begin{tabular}{|c|c|c|c|c|}
\hline \multirow{2}{*}{$\begin{array}{l}\text { Age wise distribution of } \\
\text { subjects }(n=594) \\
n(\%)\end{array}$} & \multicolumn{2}{|c|}{ Sickle allele } & \multirow[b]{2}{*}{$\begin{array}{c}\beta \text { thalassemia allele } \\
n(\%)\end{array}$} & \multirow[b]{2}{*}{$\begin{array}{c}\text { Alpha thalassemia alleles } \\
n(\%)\end{array}$} \\
\hline & $\begin{array}{c}\text { Heterozygous state } \\
n(\%)\end{array}$ & $\begin{array}{c}\text { Homozygous state } \\
n(\%)\end{array}$ & & \\
\hline $\begin{array}{l}1-15 \text { years } \\
310(52.2 \%)\end{array}$ & $22(7.1)$ & $12(3.9)$ & $14(4.5)$ & $148(47.7)$ \\
\hline $\begin{array}{l}>15-30 \text { years } \\
126(21.2 \%)\end{array}$ & $22(17.5)$ & $4(3.2)$ & $4(3.2)$ & $62(49.2)$ \\
\hline $\begin{array}{l}>30-45 \text { years } \\
82(13.8 \%)\end{array}$ & $10(12.2)$ & $2(2.4)$ & $2(2.4)$ & $52(63.4)$ \\
\hline $\begin{array}{l}>45 \text { years } \\
76(12.8 \%)\end{array}$ & $6(7.9)$ & $0(0.0)$ & $0(0.0)$ & $40(52.6)$ \\
\hline Total & $60(10.1)$ & $18(3.03)$ & $20(3.37)$ & $302(50.8)$ \\
\hline
\end{tabular}

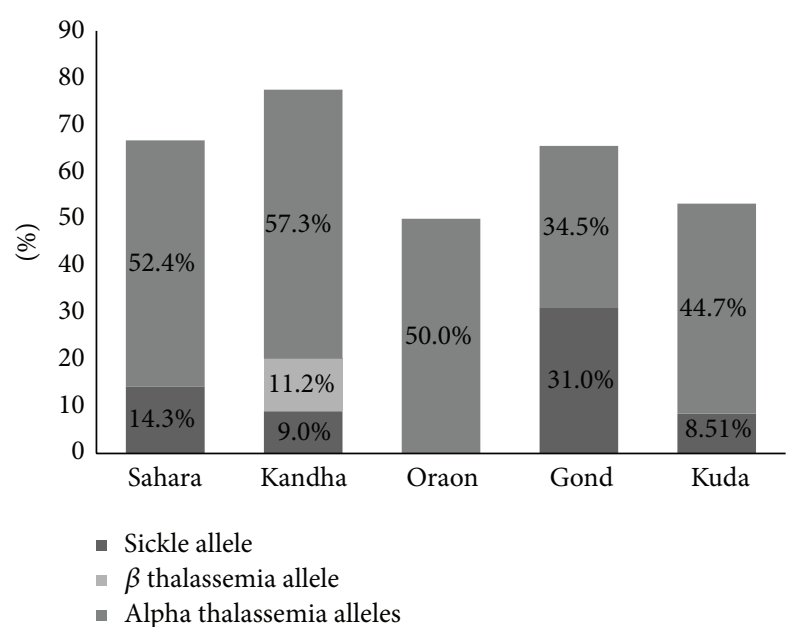

FIGURE 3: Prevalence of alpha thalassemia allele, sickle allele, and $\beta$ thalassemia allele in five tribal communities in study subjects.

thalassemia) were found. Sahara, Gond, and Kuda had two alleles (sickle allele and alpha thalassemia) and the Oraon had only one allele, that is, alpha thalassemia.

The prevalence of sickle allele, alpha thalassemia allele and $\beta$ thalassemia allele were compared in four age groups (1-15 years, $>15-30$ years, $>30-45$ years and $>45$ years $)$ of the subjects (Table 2).

\section{Discussion}

Various evolutionary forces such as natural selection against malaria and social behaviors like endogamy are the most likely contributing factors for increased prevalence of inherited hemoglobin disorders in India [11]. However there is lack of well-designed epidemiological and molecular studies to confirm the malaria hypothesis for the high prevalence of these genetic disorders. Moreover accurate estimation of these hemoglobin disorders would be desirable for proper utilization of health resources in a developing country like India.

In the state of Odisha, tribes constitute $22.1 \%$ of the total population and they are $9.7 \%$ of the total tribal population of
India [15]. More than $60 \%$ of these tribal populations live in malaria endemic areas. Various epidemiological studies and malariometric surveys carried out in this population revealed high frequency of $P$. falciparum malaria, as malaria control in such settlements is inadequate due to technical and operational problems [19]. This is the first community study to estimate the frequency of deletional alpha thalassemia $\left(\alpha^{-3.7}\right.$ and $\alpha^{-4.2}$ ) and sickle gene and $\beta$ thalassemia in the tribal dominated state of Odisha in eastern India.

In the Indian subcontinent the prevalence of alpha thalassemia alleles varies from 10 to $25 \%$, although in a few localized communities they are found in $80 \%$ of the population [26]. The prevalence of alpha thalassemia in the tribal population of the state of West Bengal and Assam in eastern India has been studied in detail. In Santals of West Bengal the prevalence was $80 \%[8,9]$, whereas in Assam the frequency in the Garos and Ahoms tribe was $36.3 \%$ and $11.62 \%$, respectively [9]. Population survey carried out from nine ethnic groups residing in or near the Nilgiri hills in southern India revealed interesting findings. Sickle cell trait was found in $27 \%$ of population and these heterozygotes showed a trimodal distribution of the $\mathrm{HbS}$ concentration postulating the presence of genotypes with two $(-\alpha /-\alpha)$, three $(-\alpha / \alpha \alpha)$, and four $(\alpha \alpha / \alpha \alpha)$ active $\alpha$ globin gene. The concentration of $\mathrm{HbS}$ was low (27\%) and these subjects had microcytic and hypochromic red cells indicating high prevalence of alpha thalassemia. Although alpha thalassemia was not confirmed by any molecular method, the authors hypothesized that high prevalence of both alpha thalassemia and sickle cell trait in these populations could be due to selection pressure exerted by hyperendemic $P$. falciparum malaria in this region [27].

There is no cross sectional community based study on the prevalence of alpha thalassemia in the tribal population of western Odisha. In an earlier hospital based study conducted on sickle cell disease patients attending to Veer Surendra Sai Medical College, Burla, the prevalence of alpha thalassemia was found to be $54.5 \%$ with an allelic frequency of 0.29 [7]. In the present study, the prevalence of alpha thalassemia was highest (56.2\%) in Kandha and lowest in Gond (34.5\%). $\alpha^{-3.7}$ deletion was ubiquitous in all the tribes whereas $\alpha^{-4.2}$ was observed in Kandha, Kuda, and Sahara tribes. Malaria is the foremost public health problem in this part of Odisha [19]. 
$15 \%$ of all admissions in the Department of Internal Medicine are due to severe malaria especially in the rainy season of June to September. Recently we undertook a study on the influence of alpha thalassemia on the severity of $P$. falciparum malaria in this region. We observed that alpha thalassemia had a protective effect against severe $P$. falciparum malaria (Supplementary table in Supplementary Materials available online at http://dx.doi.org/10.1155/2014/745245).

In the Indian subcontinent the prevalence of sickle gene is found to be $5-40 \%$ with an allelic frequency of $0.031-0.41$ [28]. The western part of Odisha lies in the high prevalence zone. The prevalence of sickle gene in the tribal population as reported from various Indian states is $0-24 \%$ in Maharashtra [29], 24\% in Chhattisgarh [30], 6.9-18.65\% in Southern Gujarat [31], and 9.2\% in Rajasthan [32]. In a hospital based study, the prevalence of sickle allele has been reported to be $8.2 \%$ in the tribal population of western Odisha [14]. In this study the prevalence of sickle allele was $13.1 \%$ with an allelic frequency of 0.08 . Sickle gene was found in four out of the five tribes studied. The prevalence was highest (31.0\%) in Gond with an allelic frequency of 0.17 . Sahara tribe constituted the majority of the population (42.4\%) and the prevalence of sickle allele was $14.3 \%$ in them which is higher than the earlier report of Kar [14]. Kandha was the largest tribe in the district of Kalahandi. The prevalence of sickle allele was found to be $9.0 \%$ in Kandha of Odisha state which is similar to earlier report by Sharma et al. [33]. For the first time we studied the Kuda (Mirdhas) tribe of western Odisha and the prevalence of sickle allele was lowest (8.51\%) with an allelic frequency of 0.05 . Sickle allele was not found in Oraon tribe. Similar finding has been reported by Kaur et al. [34]. The lack of sickle allele in the Oraon tribe could be due to recent migration of the Oraon population with founder effect. In this study this population constituted of only $2 \%$ of the total subjects studied and were localized to one village.

We compared the prevalence of sickle allele in the various age groups. Subjects with sickle allele in the heterozygous state $(10.1 \%, 60 / 594)$ were distributed in all age groups and $10.0 \%(6 / 60)$ subjects survived beyond 45 years of age indicating better survival in comparison to sickle cell anemia subjects. Eighteen subjects $(3.03 \%, 18 / 594)$ were found to have homozygous sickle cell anemia. Majority of these subjects $(66.7 \%, 12 / 18)$ were in the $1-15$ years age group. Their proportion progressively decreased with increasing age of the population and none of the subjects were alive beyond $>45$ years of age. This finding highlights the facts that sickle cell anemia patients have increased mortality and very few of them survive beyond the fifth decade. The age-wise distribution for alpha thalassemia subjects (both heterozygous and homozygous state) was similar to that of sickle allele in the heterozygous state.

In a multicentric study of college students and pregnant women, the overall prevalence of $\beta$ thalassemia trait was found to be $2.78 \%$ in India [35]. The data on prevalence of $\beta$ thalassemia in different tribal populations in India is scarce. The prevalence of $\beta$ thalassemia trait in the Adivasi of Gujarat ranged from $1.1 \%$ to $2.24 \%$ [31]. In a study on the health status of tribes of Odisha, the prevalence of thalassemia allele varied from $1.9 \%$ in Kharias to $8 \%$ in Santala [19]. In our study the prevalence of $\beta$ thalassemia allele was $3.4 \%$ in tribes studied which is comparable to the earlier reports. Interestingly this allele was confined in the Kandha tribe only. The only mutation found in the $\beta$ thalassemia subjects was IVS1-5 $(\mathrm{G} \rightarrow \mathrm{C})$.

\section{Conclusion}

Inherited hemoglobin disorders like alpha thalassemia and sickle gene are highly prevalent in the tribes of western Odisha. The high prevalence of deletional alpha thalassemia and sickle gene (in heterozygous or homozygous state) in tribal population in this region is probably due to selection pressure of endemic malaria in this part of India. This population is ideally suited for studying the mechanism of interaction and pathophysiological basis of malaria protection by inherited hemoglobin disorders like alpha thalassemia and sickle gene.

\section{Conflict of Interests}

The authors declare that they have no conflict of interests.

\section{Acknowledgments}

This study was supported by research funding from Department of Science and Technology (DST), New Delhi, Government of India; Indian Council of Medical Research, (ICMR), New Delhi; and National Health Mission (NHM), Odisha.

\section{References}

[1] D. J. Weatherall and J. B. Clegg, The Thalassaemia Syndromes, chapter 1, Blackwell Science, Oxford, UK, 4th edition, 2001.

[2] A. Christianson, C. P. Howson, and B. Modell, March of Dimes Global Report on Birth Defects, March of Dimes Birth Defects Foundation, New York, NY, USA, 2006.

[3] A. V. S. Hill, "Malaria resistance genes: a natural selection," Transactions of the Royal Society of Tropical Medicine and Hygiene, vol. 86, no. 3, pp. 225-226, 1992.

[4] D. J. Weatherall and J. B. Clegg, "Inherited haemoglobin disorders: an increasing global health problem," Bulletin of the World Health Organization, vol. 79, no. 8, pp. 704-712, 2001.

[5] R. Galanello, A. Eleftheriou, J. Traeger-Synedinos et al., Prevention of Thalassaemia and Other Haemoglobin Disorders, vol. 1, Thalassaemia International Federation Publications, Nicosia, Cyprus, 2003.

[6] C. L. Harteveld and D. R. Higgs, " $\alpha$-thalassaemia," Orphanet Journal of Rare Diseases, vol. 5, p. 13, 2010.

[7] A. E. Kulozik, B. C. Kar, G. R. Serjeant, B. E. Serjeant, and D. J. Weatherall, "The molecular basis of $\alpha$ thalassemia in India. Its interaction with the sickle cell gene," Blood, vol. 71, no. 2, pp. 467-472, 1988

[8] B. Gajra, S. Chakrabarty, B. Sengupta et al., "Molecular heterogeneity of alpha thalassaemia and its relationship with other haemoglobinopathies in a tribal population from Sian village, Birbhum, West Bengal," The Nucleus, vol. 46, no. 1-2, pp. 29-33, 2003. 
[9] R. Sen, S. Chakrabarti, B. Sengupta et al., “ $\alpha$-thalassemia among tribal populations of Eastern India," Hemoglobin, vol. 29, no. 4, pp. 277-280, 2005.

[10] V. H. Sankar, V. Arya, D. Tewari, U. R. Gupta, M. Pradhan, and S. Agarwal, "Genotyping of alpha-thalassemia in microcytic hypochromic anemia patients from North India," Journal of Applied Genetics, vol. 47, no. 4, pp. 391-395, 2006.

[11] R. Dastidar and G. Talukder, "The molecular basis of Alpha thalassaemias in India: a review. Anthropology today: trends, scope and applications," Anthropology, vol. 3, pp. 349-354, 2007.

[12] S. Dubey, S. Pathak, R. Upadhyay et al., "Prevalence of alpha thalassemia type II in Gond tribe of Shahdol district of Madhya Pradesh, India," Journal of Microbiology and Biotechnology, vol. 2, no. 4, pp. 13-19, 2013.

[13] P. Purohit, R. S. Mashon, S. Patel et al., "Clinical and molecular characterization of $\mathrm{Hb} \mathrm{Hofu}$ in eastern India," International Journal of Laboratory Hematology, vol. 36, pp. 71-76, 2014.

[14] B. C. Kar, "Sickle cell disease in India," The Journal of the Association of Physicians of India, vol. 39, no. 12, pp. 954-960, 1991.

[15] Census of Odisha, "Directorate of Field Publicity Bhubaneswar," Odisha, India, 2011, http://dfp.nic.in/bhubaneswar/Census.aspx.

[16] F. B. Piel, A. P. Patil, R. E. Howes et al., "Global distribution of the sickle cell gene and geographical confirmation of the malaria hypothesis," Nature Communications, vol. 1, no. 8, article 104, 2010.

[17] World Health Organization, World Malaria Report 2012, World Health Organization, Geneva, Switzerland, 2012.

[18] "Epidemiological report up to the month of September 20122013," Directorate of National Vector Borne Disease Control Programme (NVBDCP), India, http://nvbdcp.gov.in/Doc/malMES-Sept13.pdf.

[19] "Health status of primitive tribes of Orissa," ICMR Bulletin, vol. 33, no. 10, 2003.

[20] F. B. Piel, A. P. Patil, R. E. Howes et al., "Global epidemiology of sickle haemoglobin in neonates: a contemporary geostatistical model-based map and population estimates," The Lancet, vol. 381, no. 9861, pp. 142-151, 2013.

[21] A. G. Evans and T. E. Wellems, "Co-evolutionary genetics of Plasmodium malaria parasites and their human hosts," Integrative and Comparative Biology, vol. 42, no. 2, pp. 401-407, 2002.

[22] J. M. Old and D. R. Higgs, "Gene analysis," in The Thalassemia. Methods in Hematology, D. J. Weatherall, Ed., vol. 6, pp. 74-101, Churchill Levingstone, Edinburgh, UK, 1983.

[23] D. Y. Wu, L. Ugozzoli, B. K. Pal, and R. B. Wallace, "Allelespecific enzymatic amplification of $\beta$-globin genomic DNA for diagnosis of sickle cell anemia," Proceedings of the National Academy of Sciences of the United States of America, vol. 86, no. 8, pp. 2757-2760, 1989.

[24] J. M. Old, "Screening and genetic diagnosis of haemoglobin disorders," Blood Reviews, vol. 17, no. 1, pp. 43-53, 2003.

[25] S. S. Chong, C. D. Boehm, D. R. Higgs, and G. R. Cutting, "Single-tube multiplex-PCR screen for common deletional determinants of $\alpha$-thalassemia," Blood, vol. 95, no. 1, pp. 360$362,2000$.

[26] T. N. Williams and D. J. Weatherall, "World distribution, population genetics, and health burden of the hemoglobinopathies," Cold Spring Harbor Perspectives in Medicine, vol. 2, Article ID a011692, 2012.

[27] G. Brittenham, B. Lozoff, and J. W. Harris, "Sickle cell anemia and trait in southern India: further studies," American Journal of Hematology, vol. 6, no. 2, pp. 107-123, 1979.
[28] A. C. Gorakshakar, "Epidemiology of sickle hemoglobin in India," in Proceeding of the National Symposium on Tribal Health, pp. 103-108, 2006.

[29] B. P. Urade, "Haemoglobin $S$ and $\beta^{\text {Thal }}$ : their distribution in Maharashtra, India," International Journal of Biomedical Science, vol. 9, no. 2, pp. 75-81, 2013.

[30] A. U. Deore and B. P. Urade, "Incidence of sickle cell trait among the Mahar of Raipur, Chattisgarh," The Anthropologist, vol. 15, no. 3, pp. 377-378, 2013.

[31] A. P. Patel, M. R. Naik, N. M. Shah et al., "Prevalence of common hemoglobinopathies in Gujarat: an analysis of a large population screening program," National Journal of Community Medicine, vol. 3, no. 1, pp. 112-116, 2012.

[32] S. Mandot, V. L. Khurana, and J. K. Sonesh, "Sickle cell anemia in garasia tribals of Rajasthan," Indian Pediatrics, vol. 46, no. 3, pp. 239-240, 2009.

[33] J. C. Sharma, K. Sharma, and R. S. Mohan, "A study of the genetic traits in the Khond tribe of Orissa," Journal of the Indian Anthropological Society, vol. 20, no. 50, 1985.

[34] M. Kaur, C. B. S. Dangi, M. Singh et al., "Burden of sickle cell diseases among tribes of India- a burning problem," International Research Journal of Pharmaceutical and Applied Sciences, vol. 3, no. 1, pp. 60-80, 2013.

[35] D. Mohanty, R. B. Colah, A. C. Gorakshakar et al., "Prevalence of $\beta$-thalassemia and other haemoglobinopathies in six cities in India: a multicentre study," Journal of Community Genetics, vol. 4, pp. 33-42, 2013. 


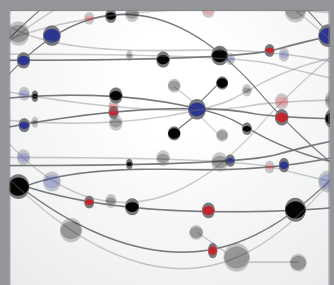

The Scientific World Journal
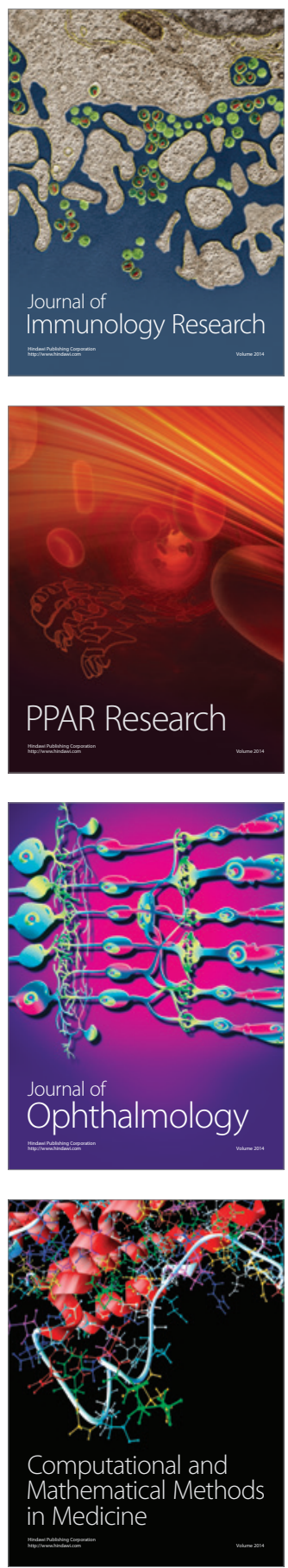

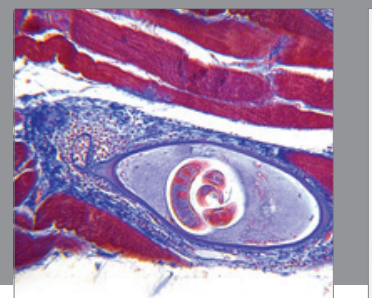

Gastroenterology

Research and Practice
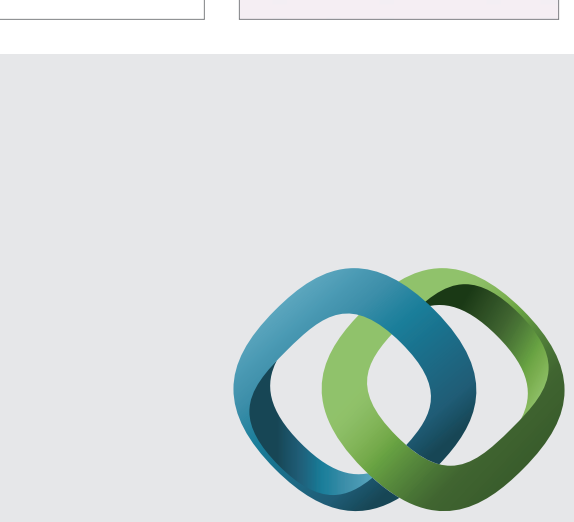

\section{Hindawi}

Submit your manuscripts at

http://www.hindawi.com
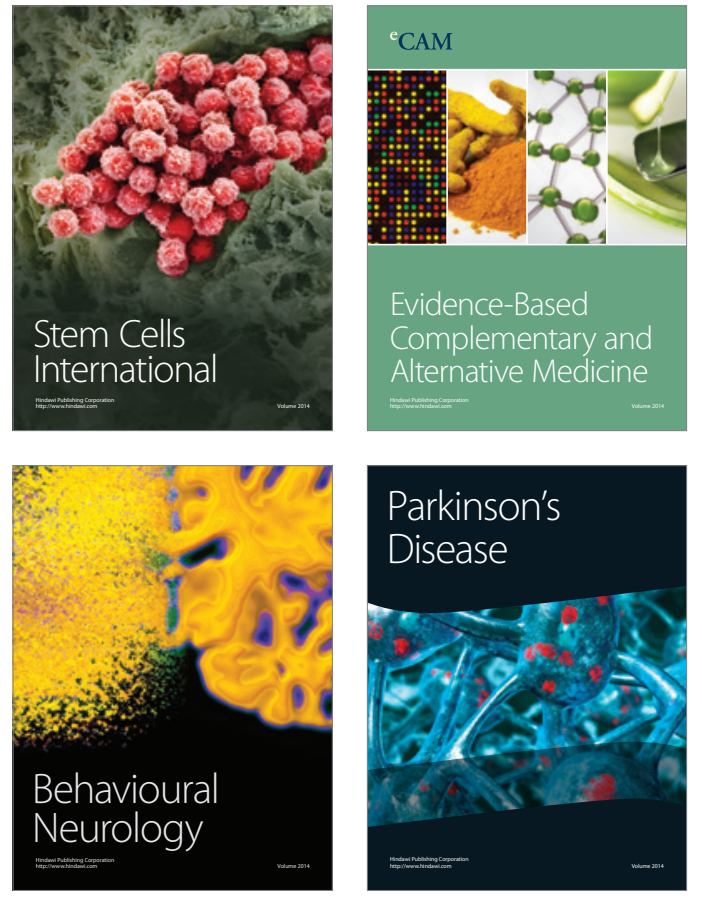
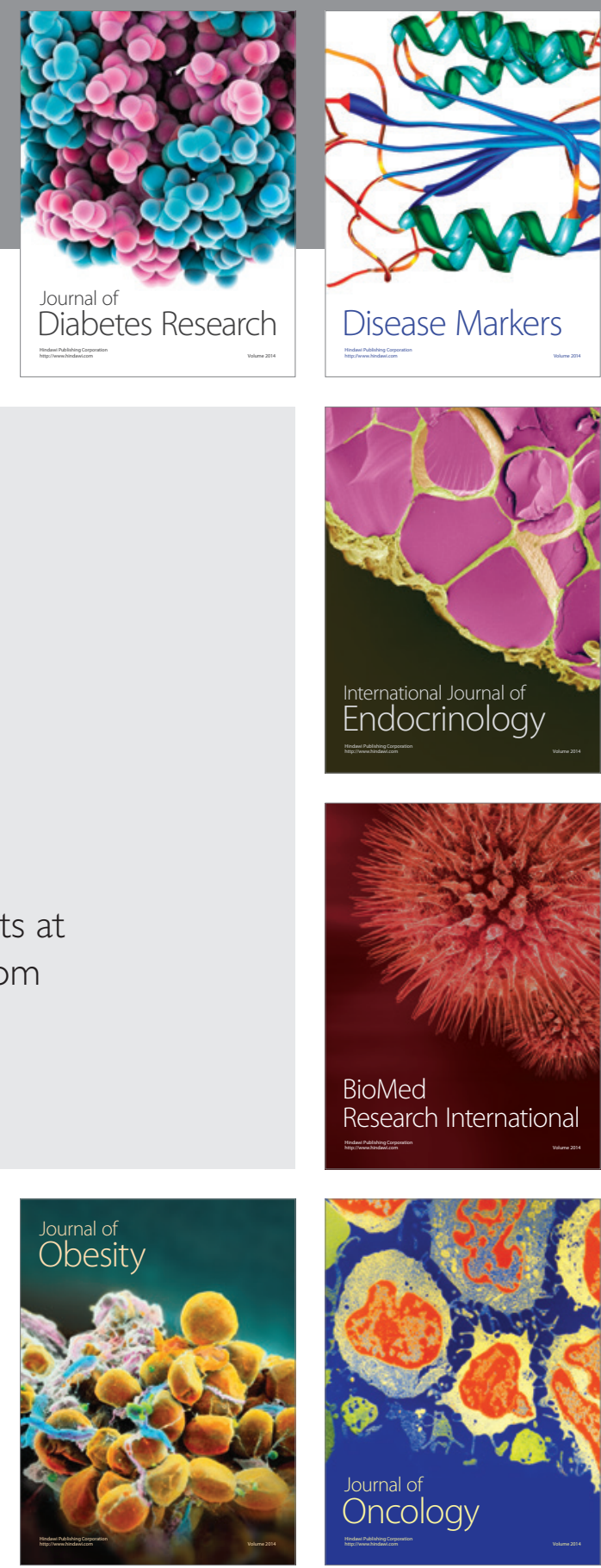

Disease Markers
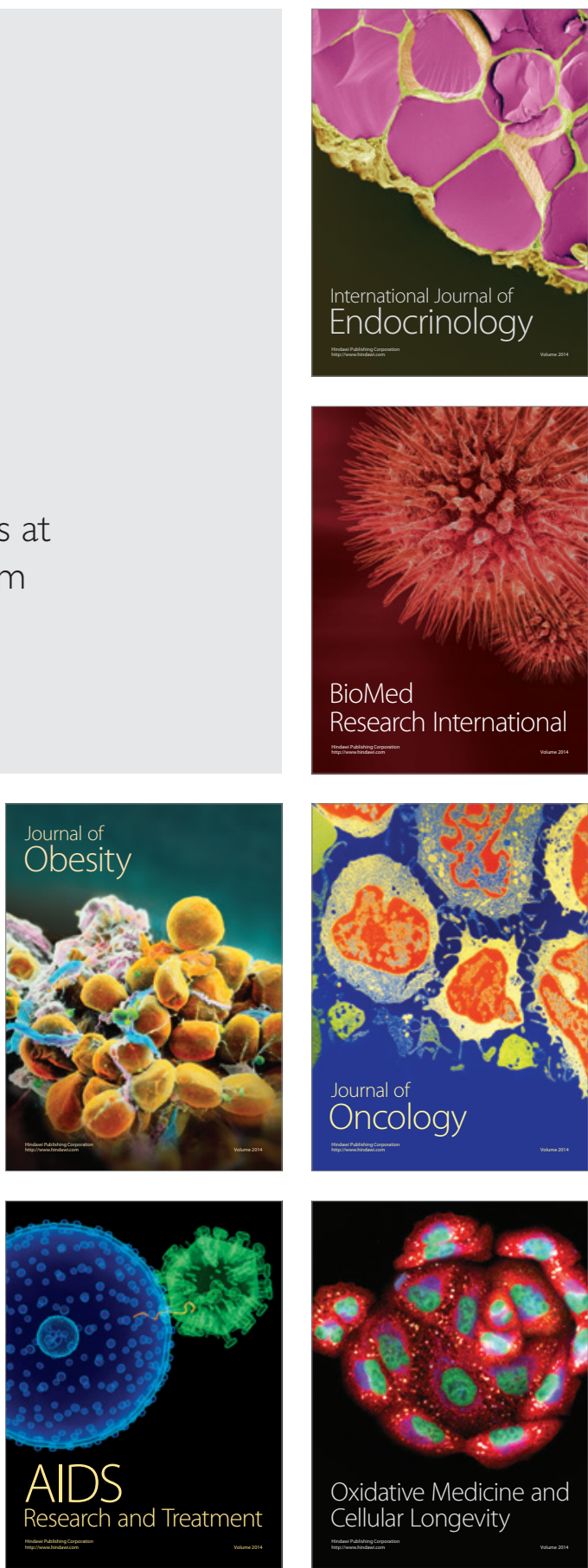